\title{
Alzheimer Type II Astrocyte
}

National Cancer Institute

\section{Source}

National Cancer Institute. Alzheimer Type II Astrocyte. NCI Thesaurus. Code C120911.

An abnormal and pathological astrocyte which appears enlarged and metabolically

hyperactive. It is characterized by the presence of vesicular and basophilic nuclei. This cell type is not associated with Alzheimer's Disease. 